\title{
VIEWPOINT Accelerating regenerative grazing to tackle farm, environmental, and societal challenges in the upper Midwest
}

Elisabeth Spratt, Jane Jordan, Jonathan Winsten, Pete Huff, Caroline van Schaik, Jane Grimsbo Jewett, Meghan Filbert, Jared Luhman, Erin Meier, and Laura Paine

\section{REGENERATIVE GRAZING AS A SOLUTION}

Regenerative livestock grazing is an agroecological approach for transforming the performance of modern agriculture. With a growing body of research complemented by anecdotal evidence, this approach is increasingly understood to be a "winwin-win" for farmers, society, and the environment. This paper aims to define regenerative grazing and its benefits, and to sharpen focus on its rapid expansion.

For the purposes of this paper, regenerative grazing is an agricultural practice that uses soil health and adaptive livestock management principles to improve farm profitability, human and ecosystem health, and food system resiliency. Applicable in both annual and perennial forage systems, such grazing builds on ecological principles and the relationship between grasslands and ruminants (Knapp et al. 1999). It is based on long-standing Indigenous land stewardship of native prairie and savanna. Regenerative grazing typically maintains rest-rotation cycles: short periods of dense grazing followed by long forage rest periods to support vegetative recovery. Regenerative grazing is a component of regenerative agriculture (Lal 2020), which emphasizes reduction or elimination of synthetic inputs and tillage; increased diversity of plant, animal, and microbial life; and generation of sufficient revenue to build viable farm businesses and fairly compensate farm labor.

This paper provides an overview of opportunities to increase regenerative grazing in the Upper Midwest of the United States, specifically in the Upper Mississippi River Basin (UMRB). Agriculture in the UMRB is dominated by conventional corn (Zea mays L.) and soybean (Glycine max [L.] Merr.) production, much of which is used for animal feed. The region's emphasis on productivity has been hard on both soils and farms. Decades of intensive tillage and synthetic inputs have resulted in nutrientladen sediment washing or blowing away, impairing aquatic ecosystems and threatening the livelihoods of interconnected Mississippi River and Gulf of Mexico communities (Jacobson et al. 2011; Alexander et al. 2008). Declining soil health and increasing dependence on synthetic inputs are also economic threats to UMRB farms (Eswaran et al. 2001). These trends reduce the resiliency of farms to withstand increasingly frequent extreme weather.

However, movements to reverse the negative environmental and economic trends on UMRB farms, often farmer-led, have made progress over the past decades. Adoption of conservation paradigms such as no-till and cover cropping and organic certification have helped many producers advance toward regenerative practices. These shifts-toward lower impact, diversified production-have created opportunities for reintegrating livestock grazing as a viable tool for farms while building soil health and its accompanying environmental and societal benefits. This paper presents a shared context of such efforts and offers recommendations on expanding regenerative grazing in the Upper Midwest.

\section{RACIAL EQUITY AND REGENERATIVE GRAZING}

Truly regenerative solutions must be socially responsible in addition to being economically and ecologically sound. The forced expulsion of Native Americans from the land and systematic subjugation and marginalization of African Americans in the formal agricultural economy have profoundly shaped today's agricultural landscape (Dunbar-Ortiz 2014; Horst and Marion 2018). Compounding historic injustices is the current production system that depends on undervalued labor from Latinx people and other people of color (Smolski 2019). Agricultural production models cannot be regenerative without explicit focus on equitable and restorative access to land, financing, legal protections, assistance, and platforms
(UCS and HEAL Food Alliance 2020). We highlight several potential channels in the "Recommendations" section of this paper, but acknowledge that we do not address and are still learning all that is required for social and economic transformation, which necessitates the inclusion and leadership of Black, Indigenous, and other people of color (BIPOC).

\section{PRACTICAL CASE FOR \\ REGENERATIVE GRAZING}

Regenerative Grazing as a System. Regenerative grazing systems create an interdependent web of on- and off-farm impacts, some of which are well-proven and some of which need more research (figure 1). Increased forage production through pasture management leads to better soil structure and biology (Glover et al. 2010). Soil health improvements in turn lead to even better forage production and improved animal health and nutrition (Paine et al. 1999). Improved soil function may also increase local resilience to extreme weather events through better water retention (Park et al. 2017a). Healthier animals lead to societal benefits like reduced dependence on and lower resistance risk to anthelmintics and

Elisabeth Spratt is senior program associate in the Wallace Center at Winrock International, St. Louis, Missouri. Jane Jordan is program associate in the Wallace Center at Winrock International, Lewisburg, Pennsylvania. Jonathan Winsten is senior agricultural economist at Winrock International, Burlington, Vermont. Pete Huff is co-director of the Wallace Center at Winrock International, Menomonie, Wisconsin. Caroline van Schaik is Driftless Area coordinator of the Upper Mississippi River Initiative of the Izaak Walton League and a grazier near New Hartford, Minnesota. Jane Grimsbo Jewett is associate director of the Minnesota Institute for Sustainable Agriculture at the University of Minnesota and grazier in Palisade, Minnesota. Meghan Filbert is livestock program manager at Practical Farmers of lowa, Ames, lowa. Jared Luhman is soil health lead of the Sustainable Farming Association and grazier in Goodhue, Minnesota. Erin Meier is director of Green Lands Blue Waters, St. Paul, Minnesota. Laura Paine is outreach specialist at the University of Wisconsin, Madison, Wisconsin.

Received December 9, 2020. 


\section{Figure 1}

The suite of interlinked on- and off-farm benefits from regenerative grazing in the Upper Mississippi River Basin.

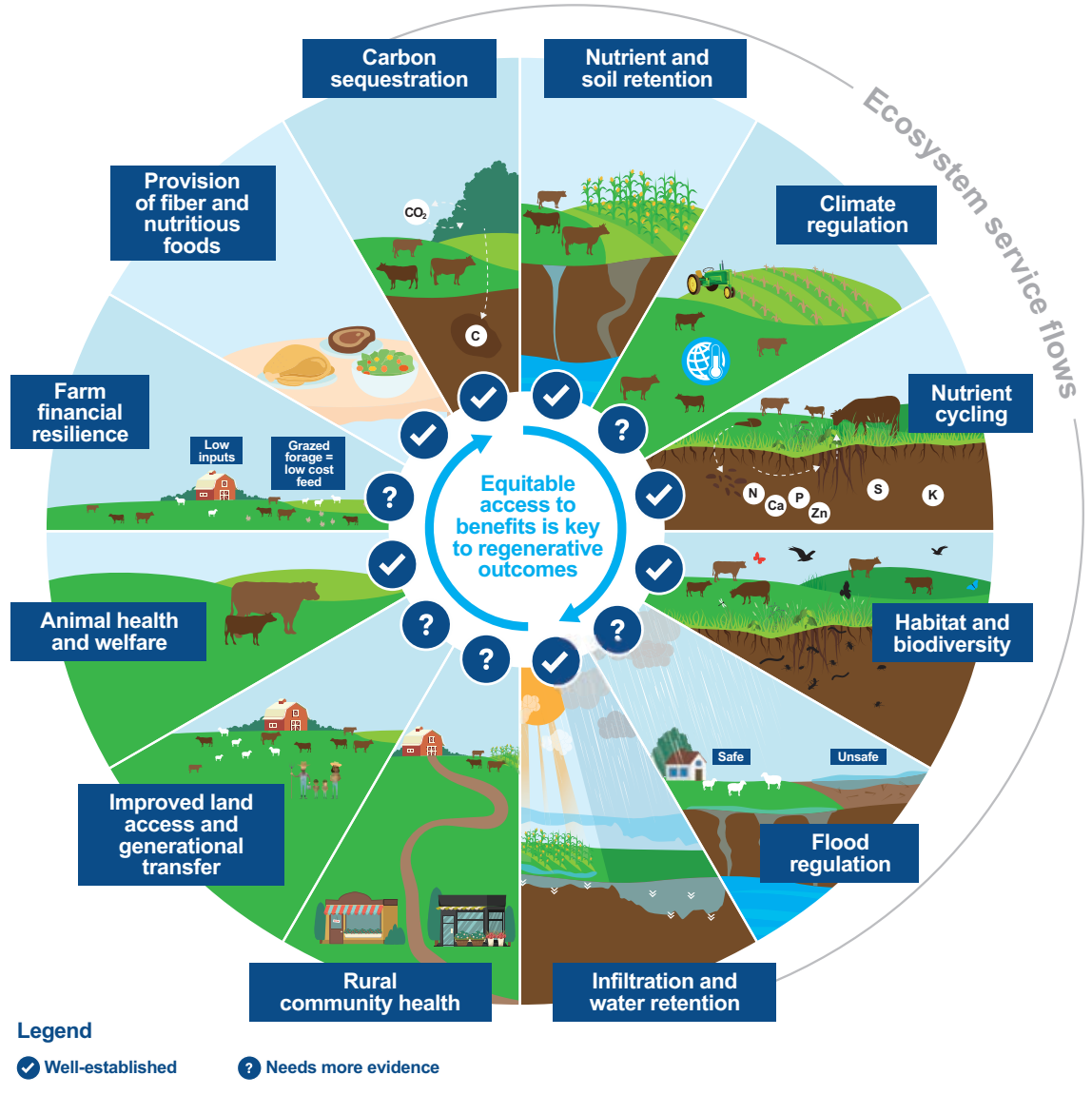

antibiotics (Waller 2006) and possibly to improved human nutrition (Provenza et al. 2019). Reduced input costs (Taylor and Field 1995) from improved soil and herd health can lead to improved farm profitability (USDA NRCS 1996). A local fabric of profitable farms can increase employment and support a broader set of food and farming-related businesses (Tuck and Pesch 2019; Rosset 2000). These changes and their positive feedback loops are inextricably linked. Consequently, while separating their study may sometimes be illustrative, we emphasize that regenerative agriculture requires a systems approach.

Farm Financial Resilience. Farmers are business operators in a highly competitive industry. Positive financial performance over the long-term is essential for each farm's continued operation. The ability to withstand volatility in input costs and revenue is the essence of financial resilience, assets per animal. For example, a dairy farm with a 60-cow tie-stall barn could adopt regenerative grazing and use low-cost loose housing and an appropriate highthroughput milking parlor to expand the herd and reduce fixed costs per unit of milk produced (Jewett 2018). In some cases, this may require divesting of some assets that are no longer necessary for the grazing system.

Ecosystem Services. Regenerative grazing systems can produce significant ecosystem services on and off the farm (Franzleubbers et al. 2012) that have value-monetary and otherwisebeyond the farm gate. Unlike annual row-crop systems and conventionally grazed pastures, regeneratively grazed pastures maintain dense, diverse stands of living plants, which can prevent erosion, improve soil fertility, and reduce nutrient runoff due to increased water infiltration (Park et al. 2017b). Perennial pasture also improves water quality (Dinnes et al. 2002) and can increase soil water storage capacity through organic matter accrual (Rawls et al. 2003). The diverse combination of fibrous and tap-rooted systems of perennial pasture promote healthy soils, which can absorb heavy rains, thereby mitigating nutrient and sediment runoff, downstream flooding, and drought (Basche and DeLonge 2019; Bharati et al. 2002). Annual cropping systems that integrate livestock (such as grazing cover crops) can provide the ecosystem services of more diverse crop rotations and cover crops. This integration can provide yearround forage availability and soil cover that is critical to erosion control and moisture retention. Regeneratively grazed pastures can also provide habitat for insects and birds without sacrificing productivity (Goosey et al. 2019; Lwiwski et al. 2015; Lyons et al. 2000; Paine and Ribic 2002; Temple et al. 1999).

On a global scale, regenerative grazing has potential for climate change mitigation through a range of mechanisms, including decreased reliance on fossil fuels and synthetic fertilizers, as well as increased carbon (C) assimilation by perennial plant communities and sequestration in the soil (Rotz et al. 2009). Relative to grain feeding, grazing can result in more enteric methane $\left(\mathrm{CH}_{4}\right)$ per unit of output. However, relative to 
conventional grazing, regenerative grazing may reduce enteric $\mathrm{CH}_{4}$ due to higher digestibility of grazed forage (Thompson and Rowntree 2020). The conversion of grassland ecosystems to annual cropping is a proven contributor to global climate change just as reconstructing perennial systems is an important part of climate change mitigation (Ahlering et al. 2016). It is important to add, however, that the magnitude and stability of $\mathrm{C}$ sequestration generated by this transition is highly sensitive to soil texture, land use history, weather, and grazing regime (Conant et al. 2017).

Animal Health and Welfare. Animal health and welfare can be improved through regenerative grazing, which generally results in lower stress and lower incidence of disease in the herd. This can result in reduced somatic cell counts and bacteria in milk (Goldberg et al. 1992), reduced lameness and feet and leg injuries (Haskell et al. 2006), and reduced culling rates (T. Kriegel, personal communication, November 2020). Silvopasture, a regenerative agriculture practice that combines tree crops, forage, and livestock, provides shade to reduce animal heat stress and simultaneously increases the flow of ecosystem services like C storage (England et al. 2020). Improved animal health can reduce the costs for medicines and veterinary services, as well as the costs for replacing culled animals.

Rural Community and Regional Economic Health. As large economic forces drive smaller farms out of business, regenerative grazing has emerged as a pathway to profitable farm businesses. In addition to improved profitability for dairy and beef farms, regenerative grazing provides an opportunity for row crop farmers to diversify their operations and create additional revenue streams (Barbieri et al. 2008). Multispecies grazing can also add enterprise diversity and help pay for grazing infrastructure. (Walker 1994).

Improved farm financial resilience has implications for the overall health of rural communities. Younger generations may have more entry points and opportunities to grow their own farm businesses. More families and family members remaining on the land strengthen the social and economic fabric of rural communities; they fill schools, patronize grocery stores, populate first responder units, and participate in their communities (Peters 2002). Successful local farms also support many rural businesses directly, including input suppliers, fencing contractors, and large animal veterinarians, and milk and meat handlers and processors may develop to serve rural regions (Deller 2019).

There are other off-farm effects to consider. Perennial grazing systems create an aesthetic working landscape that encourages agritourism as another source of revenue for farms and rural communities (Gao et al. 2014). In the world of markets, the COVID-19 pandemic illustrates the benefit of local and regional supply chains that are decentralized, diversified, and nimble enough to pivot according to local demand. Increased water retention and storage on regenerative pastures (Gerla 2007) may reduce emergency response and infrastructure costs (such as road and culvert repair) from extreme weather events. More evidence and examples are needed to quantify these community benefits in aggregate.

\section{CURRENT RESOURCES AND RECOMMENDATIONS FOR \\ FACILITATING TRANSITION TO REGENERATIVE GRAZING}

A suite of policies and programs support graziers, with a mix of criticality, specificity, and scale (figure 2). In the sections that follow, we briefly discuss the primary areas of current support for farmers interested in regenerative grazing throughout the UMRB. For each area, we provide recommendations to support the appropriate scaling of regenerative grazing (summarized in figure 3 ).

\section{TECHNICAL ASSISTANCE AND EDUCATION: STATUS}

Through its conservation programs, the USDA provides billions of dollars in financial and technical assistance (TA) to producers to adopt conservation practices on farms and ranches (USDA 2019). Many state USDA Natural Resources Conservation Service offices have grazing experts who provide TA on grazing and grazing plan development. Those offices also maintain lists of certified Technical Service Providers who work with farmers to create grazing plans. States also fund TA through university cooperative extensions. The TA provided through these programs and the Natural Resources Conservation Service is not uniform across states. Further, recommendations are not always tailored to regenerative grazing, largely due to limited staffing and expertise. There also have been reductions in state extension budgets that have reduced the availability of state-funded TA.

TECHNICAL ASSISTANCE AND
EDUCATION: RECOMMENDATIONS
Build on University and Technical College
Research and Education on Grazing. Many
land grant university animal science pro-

\section{Figure 2}

Current system of support for graziers, by criticality of support, availability, and adaptivity to supporting regenerative graziers.

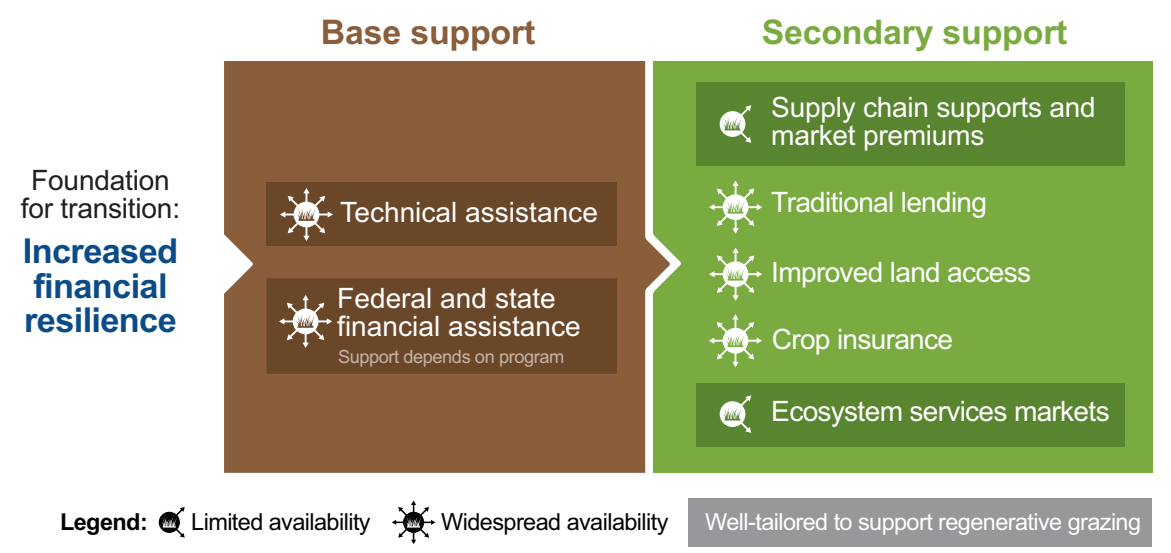




\section{Figure 3}

Recommendations to accelerate the trajectory of regenerative grazing adoption.

\section{Foundation for transition: Increased financial resilience}
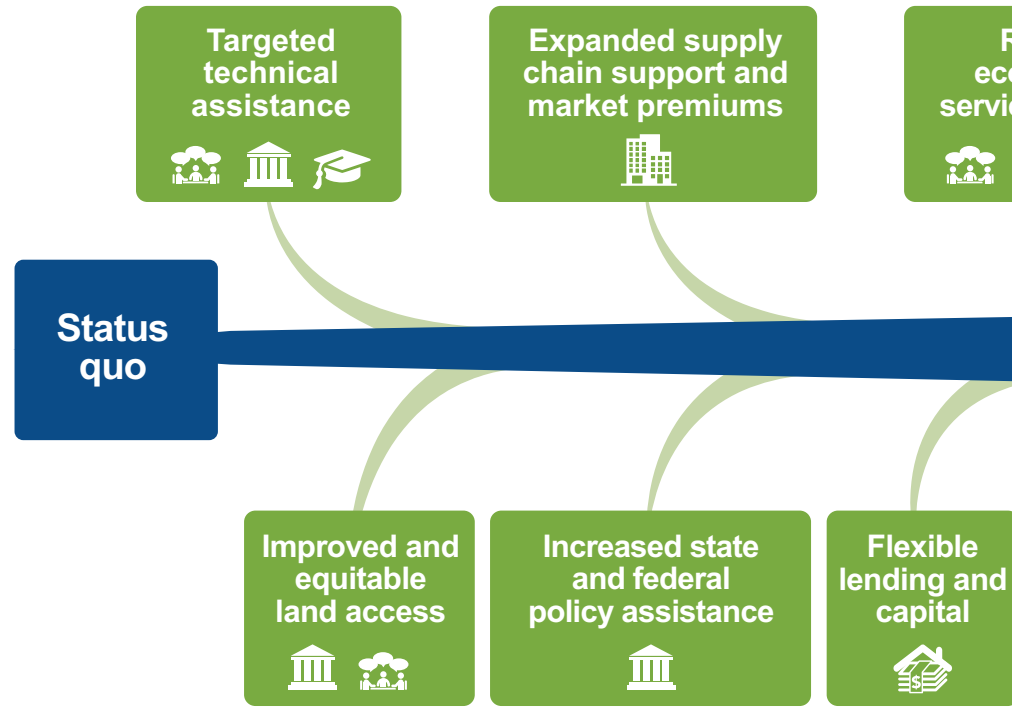

Robust ecosystem service markets

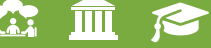

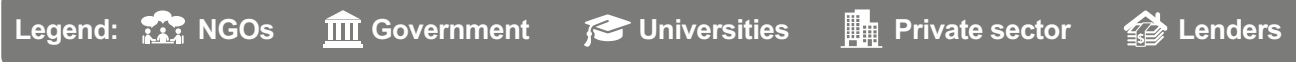

grams still focus primarily on feedlot beef or confinement dairy production, priorities that then shape research, outreach, and education. Integrating regenerative grazing into university priorities would contribute to a broader swathe of committed educators and researchers, ensuring that future producers are knowledgeable about regenerative practices and are well equipped to implement them.

Expand and Coordinate Technical Assistance. Increased state and federal funding for training and certification of Technical Service Providers in regenerative grazing would provide increased opportunities for grazing planning support and quality TA on grazing. Farming is first and foremost a business; specialized TA on farm financial viability should be expanded throughout the UMRB. Since maximizing days on pasture and minimizing feed costs are critical in the context of harsh winters in the UMRB, TA should also focus on seasonal grazing systems, regional best practices, and even supply chain connectivity with producers in other regions. Increasing the coordination of TA providers through a regenerative grazing community of practice could support standardization of information, sharing of best practices, individual capacity development, and a more consistent quilt of TA across the UMRB.

\section{LAND ACCESS: STATUS}

Access to quality grazing acreage is one of the most significant hurdles for beginning farmers. Land in the Upper Midwest can be cost prohibitive, and many farmers struggle to find land suitable for their operations. Many would-be graziers find themselves leasing acres from landowners who are resistant to the implementation of new practices on their property. As the US farming population ages and nears retirement, questions around farmland transfer and succession are critical in ensuring a new generation of farmers is able to carry on. Land access is especially important for BIPOC farmers, who have faced decades of land loss and land access discrimination. A truly regenerative approach to land access should address farmland transfer back to these communities.
Many nonprofit organizations and farmer networks provide support for farm succession and transition planning. The USDA supports beginning farmers and ranchers through its Beginning Farmer and Rancher Development Program. The USDA Farm Service Agency (FSA) also provides targeted loans to beginning farmers and targets a portion of all loan funds to historically underserved farmers. Some Farm Credit institutions and private lenders also have beginning farmer lending programs, and some states, including Minnesota, offer tax incentives for land succession to a beginning farm family.

\section{LAND ACCESS: RECOMMENDATIONS}

Expand Grazing on Public Lands. Grazing on public lands can provide needed grazing acres, especially in areas experiencing development pressure or regions that are heavily commodity cropped. Regenerative grazing can contribute to conservation goals and provide a cost-effective alternative to other grassland management strategies. The Wisconsin Department of Natural Resources (DNR) has piloted a 
successful grazing public lands program on nearly 30 sites comprising nearly 5,000 ac (2,023 ha) across the state.

Public and Private Incentives to Protect and Increase Land Access. Public and private entities should prioritize legislation, funding programs, and incentives that expand and protect land access for beginning and farmers of color. Federal reforms to heirs' property laws and the expansion of USDA FSA loan programs that facilitate land acquisition by Indigenous communities are both proposed strategies to increase land access for BIPOC (UCS and HEAL Food Alliance 2020). Institutions with a vested interest in land stewardship and agriculture must also be part of this effort and should finance land repatriation to Black and Indigenous communities. More comprehensive land return efforts by private individuals and organizations could be financed by the private sector. Additionally, state and local agencies should consider tax incentives or novel use of easements to facilitate access to BIPOC farmers.

\section{FEDERAL AND STATE POLICY: STATUS}

Most current federal farm income support is delivered through subsidized revenue protection programs. These programs, such as the Agriculture Risk Coverage and Price Loss Coverage programs, continue to incentivize intensive row cropping and livestock confinement operations. There is not similar risk protection for producers of perennial or annual forages. In 2016, USDA provided more than US $\$ 3.8$ billion in corn and soybean subsidies and less than a quarter billion dollars for hay and forage (USAFacts 2019), yet nationally more farms report producing forage than producing corn or soybeans (USDA NASS 2017). Graziers also face challenges in protecting their marketing claims due to numerous, often confusing third-party certifications and a lack of regulation around country of origin labeling for beef and pork.

Conservation assistance dollars are often used in conjunction with state funds to pay for practices helpful to graziers, such as fencing, lanes, and water systems. Although federal programs like the Conservation Stewardship Program and Environmental Quality Incentives Program provide criti- cal financial assistance, current practice standards restrict regenerative practices. For example, a producer is ineligible for perimeter fencing cost-share for row crop fields, thereby undercutting support for grazing cover crops. Long waits, land ownership requirements, rigid practice standards, and inconsistent grazing recommendations in some states can all result in producer confusion, frustration, and underutilization of these programs. The Conservation Reserve Program pays farmers to take land out of annual production, but does not allow grazing and often pays more than a grazier would pay to rent the same land.

State nutrient reduction strategies (NRSs) are central to the coordinated planning efforts of the Gulf of Mexico Hypoxia Task Force. While all state NRSs include a variety of actions targeting point and nonpoint sources, agriculture is emphasized because of its significant contribution to Gulf of Mexico nutrient pollution. Grazing management is included, to various degrees, in some state NRSs; Iowa and Missouri have incorporated these practices and thus are able to estimate their contribution to nutrient management (IDALS 2017; MDC 2014).

\section{FEDERAL AND STATE POLICY: RECOMMENDATIONS}

Align Federal Policies to Better Support Regenerative Grazing Adoption and Address Market Barriers. The USDA manages billions of dollars in conservation practice funding, regulates the health and safety of livestock, oversees matters of competition, and supports the promotion and marketing of agricultural products. Shifting some of these resources to program support for regenerative grazing will ensure better environmental and economic return on investment for USDA. The next farm bill should (1) remove barriers to grazing cover crops and Conservation Reserve Program acres and institute incentives, (2) increase TA in farm bill programs and funding to state extension for grazing TA, (3) redefine country of origin labeling to ensure only US domestic beef can be labeled "Product of USA," (4) support strong grass-fed labeling standards and verification that include an exemption or cost-share option for small-scale farmers, (5) encourage supply chain innovation (such as state-run meat processing or interstate shipping agreements for state-inspected processors) that helps small and midsize producers lower the cost of production and find efficient paths to the consumer (VanDerPol and VanDerPol 2020; IDALS 2020), and (6) prioritize regenerative grazing practices in application criteria and create targeted funding pools under conservation programs (NSAC 2020).

Increase State Funding and Incentives for Grazing. Designating a small percentage of state sales taxes for conservation and water quality improvements is an effective and proven way to fund incentives for agricultural practices. Other UMRB states can replicate efforts such as Minnesota's Outdoor Heritage and Clean Water Funds and Missouri's Parks, Soils, and Water Tax to create incentives for regenerative grazing, including expanded TA. In 2018, Missouri's program contributed US $\$ 40$ million to conservation programs on the ground (MDNR 2018). Resources could also support research on incorporating regenerative grazing in cover crop management, demonstration projects, and farmer-to-farmer learning. Additionally, more states in the UMRB could replicate tax credits such as Iowa and Minnesota's beginning farmer tax credits and Wisconsin's farmland preservation tax credit to support graziers.

Coordinate Across an Array of Funding and Financing Sources. Although USDA and related state agricultural agency programs represent most public funding to farmers, there are many other public programs with goals that regenerative grazing can help to meet. These include rural development programs and state clean water revolving loan funds, among others. Coordinating agricultural and conservation program funding with these less traditional sources has the potential to help interested farmers make transformational change to their operations. Additionally, a larger mass of coordinated public funds has greater potential to leverage private sector funding streams, such as impact investments, supply chain programs, and environmental market pay- 
ments. Coordinating public funds is an important first step in creating a "basket" of incentives that facilitate more transformational change on farms. Winsten et al. (2020) describe this concept fully.

Add Regenerative Grazing to State Nutrient Reduction Strategies. If regenerative grazing were recognized for its contribution to nutrient reductions alongside other, more traditional practices, this would refocus additional state and federal resources to the practice. Thus, state NRS science committees should review available literature to assess water quality benefits of regenerative grazing for potential inclusion into NRSs, just as Iowa and Missouri have.

\section{SUPPLY CHAIN SUPPORT AND MARKET PREMIUMS: STATUS}

Demand for humanely, regeneratively produced meat and milk is growing. Some data indicate that consumption of milk and beef is declining overall, but is increasing for products with a specialty claim, leading to an overall growth in pastured and grass-fed markets. Nationwide, beef marketed with a grass-fed production claim doubled every year between 2012 and 2016, while non-grass-fed beef sales have fallen (Cheung and McMahon 2017). Clearly, there is increasing demand for animal products with health and safety attributes. Innovative efforts like the Milk with Dignity Program illustrate that consumers and end market distributors are invested in regeneration across the supply chain, including efforts to protect worker rights and ensure safe labor conditions.

Regeneratively produced foods can be more expensive, and a tension exists between properly valuing these products and equitable, widespread access to them. We acknowledge significant work left to do in creating more efficient, cost-effective distribution, increasing the buying power of many consumers, and advocating for an improved food access safety net that also values regenerative outcomes.

\section{SUPPLY CHAIN SUPPORT AND MARKET} PREMIUMS: RECOMMENDATIONS Coordinate Value Chains and Clusters of Producers. Targeted support and resourcing of "clusters" of producers pursuing regenerative grazing practices should be coordinated between farm support organizations, the private sector, and public agencies. This support will capture efficiencies in infrastructure investments and can also help aggregate livestock or grass-finished products at a volume and consistency, lowering transportation and processing costs. This clustered approach creates reliable production bases for branded programs and can also facilitate the emergence of farmer-to-farmer grazing support networks, which further learning and improve production practices.

Center Equity and Workplace Protections in Value Chain Development. A regenerative grass-fed value chain should produce safe, healthy, and accessible food for all people while creating equity and empowerment for farmers and foodchain workers. Expanding state and federal labor protections for farm and food workers-including equitable compensation, collective bargaining rights, and overtime pay - is critical to building truly regenerative value chains. These efforts will help ensure that regenerative markets protect and promote rural livelihoods while ensuring all consumers can benefit.

Meet Institutional Procurement Price Points with Blended and Transitional Products. Brands should consider opportunities for creating "better" meat and milk options at more affordable prices for end buyers with smaller budgets (e.g., public schools). These products can be blended (e.g., vegetable/beef or grass-fed/ conventional product blends), transitional (e.g., minimally grain-finished product), or even sized for smaller portions. Vegetable, lentil, or mushroom blended beef products can be a "cost neutral" strategy for increasing procurement of grass-fed beef (Health Care Without Harm 2018).

\section{TRADITIONAL LENDING: STATUS}

A variety of farm loans support graziers in their operations, including loans administered by private banks, Farm Credit, and USDA's FSA. Both farm operating loans and real estate loans require business plans, tax returns, month-by-month cash flow projections, detailed assumptions, and detailed explanation of financing needs. Because the process is well traversed for commodity grain and confinement livestock operators and less so for graziers in the Upper Midwest, lenders are often less familiar with evaluating financial information from grazing or diversified enterprise operations. Although some universities aggregate farm financial data for use by farm business consultants and lenders, these databases are generally lacking in financial data from grazing operations. Furthermore, the TA framework to support graziers does not always support financial planning at the level of detail that is required for applying for traditional farm finance. USDA's lending resources have been more focused on beginning farmers in recent years than on graziers.

\section{TRADITIONAL LENDING: RECOMMENDATION}

Tailor Traditional Lending and Pilot New Finance Mechanisms Throughout the Grass-Fed Value Chain. Most agriculture lenders need persuasive education about almost all production models outside of confinement livestock and conventional row crops. Grass-based farmers should be encouraged to support this education by entering their financials into state-wide agricultural databases, typically through university-hosted farm business education programs, which currently underrepresent grazing enterprises. Beyond traditional lending, expanded access to capital from impact investors as well as philanthropic organizations is necessary to support the growth of a healthy, robust value chain. Investment should be tailored for each actor in the grass-fed sector (including producers, processors and supporting businesses, and even brands). Organizations like Croatan Institute are leading the identification of areas ripe for investment as well as piloting mechanisms such as landsecured financing and pairing TA with financing (Electris et al. 2019).

\section{CROP INSURANCE: STATUS}

Risk reduction programs for livestock producers have long been limited when compared to those for crop producers. This is typically because of the predominance of corn and soybean production and demand for related insurance, as well as the difficulty of measuring and recording the 
grazing land production for the purposes of setting a guarantee of yield or revenue policy. While a revenue protection program for livestock producers does exist, the more relevant federal crop insurance program for pasture-based livestock producers is the Pasture, Rangeland, and Forage Pilot Insurance Program administered by the USDA's Risk ManagementAgency (RMA). This program covers forage crop losses due to drought. The Pasture, Rangeland, and Forage Program creates a safety net for pasture-based livestock producers to maintain perennial cover. However, the program struggles to accurately peg local forage values, which threatens to reduce the risk protection that crop insurance programs are intended to provide.

Some row crop insurance programs have historically discouraged livestock integration and stacked enterprises, such as disallowing the grazing of cover crops on fallowed prevent-plant acres. In 2019, the USDA RMA, which administers the federal crop insurance program, amended its policy to allow producers to graze cover crops on prevent-plant acres, an important policy shift that illustrates the potential to create a policy environment that is more hospitable to grazing.

CROP INSURANCE: RECOMMENDATION Promote and Use Forage-Based Index for Pasture, Rangeland, and Forage Insurance Program. More effective engagement with eligible farmers by the RMA to set and standardize forage values for different grazing management systems would help improve the program for broader benefit.

ECOSYSTEM SERVICES MARIKETS: STATUS

Ecosystem services markets in the UMRB with relevance to farmers and ranchers fall broadly into two categories: water quality markets and $\mathrm{C}$ markets. Water quality credit trading can allow point source polluters with high abatement costs to meet water quality obligations at a lower cost through purchase of water quality credits from other sources (usually nonpoint). These programs are geographically bound, often by watershed, and are unevenly distributed across the country. Wisconsin currently hosts one of the only water quality trading programs in the
Upper Midwest (Wisconsin DNR 2020). Demand for these markets depends on the restrictiveness of local, state, and federal water quality regulations, but increasingly sophisticated nutrient tracking and modeling technology increases the potential for the development of these markets.

Carbon markets are also increasing in relevance to graziers. Transactions between buyers and sellers are not necessarily bound by geography, although demand for $\mathrm{C}$ credits may be clustered in specific regions due to enabling policies. There is a growing interest in agricultural $\mathrm{C}$ credits in both the public and private sectors. Private entities like Indigo Ag have ambitious programs for $\mathrm{C}$ sequestration through regenerative farming practices. Greenhouse gas accounting programs like the American Carbon Registry and Verified Carbon Standard have developed C offset methodologies for grazed livestock (American Carbon Registry 2014; FAO 2014). There are, however, challenges in cost-effectively quantifying agricultural $\mathrm{C}$ offsets due to the relatively small amount of $\mathrm{C}$ per acre across many acres. The nature of agricultural $\mathrm{C}$ pools and the permanence of soil $\mathrm{C}$ are complex and still a subject of debate among soil scientists. Participation in $\mathrm{C}$ markets often requires extensive data collection and recordkeeping for farmers and ranchers.

Carbon neutral supply chain efforts are increasing, facilitated by efforts such as Native Energy's HELP BUILD model (Native Energy n.d.). Companies agree to fund activities that reduce emissions in their supply chains. Emissions reductions are quantified and verified using rigorous methods, and the companies can say they contributed to reducing these emissions. Because these models are not based on "offsets," this can avoid complications with reversal risk, and because companies are typically funding their own suppliers to reduce emissions, achieving scale and aggregation can be easier.

\section{ECOSYSTEM SERVICES MARKETS: RECOMMENDATION}

$\begin{array}{lll}\text { Continue } & \text { Funding } & \text { Research on } \\ \text { Quantifying Ecosystem } & \text { Service Flows }\end{array}$ from Regenerative Grazing. The research on ecosystem services generated by graz- ing is generally conclusive in the direction of change and provides evidence for system-wide benefits. The magnitude of these benefits, however, varies and is highly dependent on geography, management, and other site-specific factors. Additional research to establish procedures for the quantification of ecosystem service flows from perennial systems and grazing is a necessary step toward increasing the overall validity of ecosystem services monetization and the relevance of offset markets to graziers. This is especially true for soil $\mathrm{C}$ sequestration.

\section{CONCLUSION}

Regenerative agriculture and grazing can help solve some of the UMRB's most urgent challenges: the devastations of a shifting climate, poor water quality, rural community contraction, racial inequities, the financial struggle of the farm next door, and declining soil health. Yet as encompassing of environmental and societal problem solving as they are, the benefits of regenerative grazing continue to be undervalued and under-incentivized by actors ranging from federal and state governments to lenders, private sector agribusinesses, and universities. Expanding the use of regenerative practices requires a cross-cutting shift in how we think about agriculture and society (figure 3). Increased financial resilience coupled with comprehensive TA (including production and financial management) provide a foundation for additional interventions that will expand the adoption of regenerative grazing. Multifaceted systems change must be premised on a full grasp of the value of regenerative grazing in order to improve policy support, expand land access, provide supply chain supports, create flexible lending, reduce production risk, and fully reward the plethora of services provided on and beyond the farm. Further, dedicated centering of racial equity and labor justice along with targeted access to land, capital,TA, and other resources for BIPOC farmers will be crucial to ensuring this agricultural movement does not perpetuate the harms of previous movements.

A future characterized by a stable climate, resilient agroecosystems, thriving farms, and diverse, just communities throughout 
the UMRB is possible. Evidence indicates that significantly expanded adoption of regenerative grazing provides a path toward that future.

\section{ACKNOWLEDGEMENTS}

The authors developed this work as a follow-on to Franzleubbers et al. (2012) and in collaboration with the Midwest Perennial Forage Working Group of Green Lands Blue Waters (https://greenlandsbluewaters.org/).

\section{REFERENCES}

Ahlering, M., J. Fargione, and W. Parton. 2016. Potential carbon dioxide emission reductions from avoided grassland conversion in the northern Great Plains. Ecosphere 7(12):e01625.

Alexander, R.B., R.A. Smith, G.E. Schwarz, E.W. Boyer, J.V. Nolan, and J.W. Brakebill. 2008. Differences in phosphorus and nitrogen delivery to the Gulf of Mexico from the Mississippi River Basin. Environmental Science \& Technology 42(3):822-30.

American Carbon Registry. 2014. Methodology for Grazing Land and Livestock Management American Carbon Registry. https://americancarbonregistry.org/carbon-accounting/ standards-methodologies/grazing-land-and-livestock-management-gllm-ghg-methodology.

Barbieri, C., E. Mahoney, and L. Butler. 2008. Understanding the nature and extent of farm and ranch diversification in North America. Rural Sociology 73(2):205-229.

Basche A.D., and M.S. DeLonge. 2019. Comparing infiltration rates in soils managed with conventional and alternative farming methods: A meta-analysis. PLoS ONE 14(9):e0215702.

Bharati, L., K.H. Lee,T.M. Isenhart, and R.C. Schultz. 2002. Soil-water infiltration under crops, pasture, and established riparian buffer in Midwestern USA. Agroforestry Systems 56:249-257.

Cheung, R., and P. McMahon. 2017. Back to Grass: The Market Potential for U.S. Grassfed Beef. Pocantico Hills, NY: Stone Barns Center for Food and Agriculture. https://www.stonebarnscenter.org/wp-content/uploads/2017/10/ Grassfed_Full_v2.pdf.

Conant, R.T., C.P. Cerri, B.B. Osborne, and K. Paustian. 2017. Grassland management impacts on soil carbon stocks: A new synthesis. Ecological Applications 27(2):662-668.

Deller, S. 2019. The Contribution of Agriculture to the Wisconsin Economy: An Update for 2017 Madison, WI: Center for Community Economic Development, University of Wisconsin-Madison. https://economicdevelopment.extension.wisc. edu/files/2019/08/Contribution-of-Ag-to-WIEcon-4-Update.pdf.

Dinnes D.L., D.L. Karlen, D.B. Jaynes, T.C. Kaspar, J.L. Hatfield, T.S. Colvin, and C.A. Cambardella. 2002. Nitrogen management strategies to reduce nitrate leaching in tile-drained Midwestern soils. Agronomy Journal 94:153-171.

Dunbar-Ortiz, R. 2014. An Indigenous Peoples' History of the United States. Boston, MA: Beacon Press.

Electris, C., J. Humphreys, K. Lang, D. LeZaks, and J. Silverstein. 2019. Soil wealth: Investing in regenerative agriculture across asset classes. Durham, NC: Croatan Institute. http://www.croataninstitute. org/images/publications/soil-wealth-2019.pdf.

England, J.R., A.P. O'Grady, A. Fleming, Z. Marais, and D. Mendham. 2020. Trees on farms to support natural capital: An evidence-based review for grazed dairy systems. Science of the Total Environment 704:135345.

Eswaran, H., R. Lal, and P.F. Reich. 2001. Land Degradation: An overview. In Responses to Land Degradation, eds. E.M. Bridges, et al. Proceedings of the 2nd International Conference on Land Degradation and Desertification, Khon Kaen, Thailand. New Delhi, India: Oxford Press.

FAO (Food and Agriculture Organization of the United Nations). 2014. Methodology for Sustainable Grassland Management. Verra Verified Carbon Standard. Washington, DC: Verra. https://verra.org/methodology/ vm0026-methodology-for-sustainable-grasslandmanagement-sgm-v1-0/.

Franzluebbers, A., L. Paine, J. Winsten, M. Krome, M. Sanderson., K. Ogles, and D. Thompson. 2012. Well-managed grazing systems: A forgotten hero of conservation. Journal of Soil and Water Conservation 67(4):100A-104A. https://doi. org/10.2489/jswc.67.4.100A

Gao,J., C. Barbieri, and C.Valdivia. 2014. Agricultural landscape preferences: Implications for agritourism development. Journal of Travel Research 53(3):366-379

Gerla, P. 2007. Estimating the effect of cropland to prairie conversion on peak storm run-off. Restoration Ecology 15(4):720-730.

Glover, J., S.W. Culman, S.T. DuPont, W. Broussard, L. Young, M.E. Mangan, J.G. Mai, T.E. Crews, L.R. DeHaan, D.H. Buckley, H. Ferris, R.E. Turner, H.L. Reynolds, and D.L. Wyse. 2010. Harvested perennial grasslands provide ecological benchmarks for agricultural sustainability. Agriculture, Ecosystems and Environment 137:3-12.
Gloy, B.A., L.W. Tauer, and W. Knoblauch. 2002. Profitability of grazing versus mechanical forage harvesting on New York dairy farms. Journal of Dairy Science 85(9):2215-2222.

Goldberg,JJ.., E.E.Wildman,J.W. Pankey,J.R. Kunkel, D.B. Howard, and B.M. Murphy. 1992. The influence of intensively managed rotational grazing, traditional continuous grazing, and confinement housing on bulk tank milk quality and udder health. Journal of Dairy Science 75(1):96-104.

Goosey, H.B., J.T. Smith, K.M. O’Neill, and D.E. Naugle. 2019. Ground-dwelling arthropod community response to livestock grazing: Implications for avian conservation. Environmental Entomology 48(4):856-866.

Haskell, M., L.J. Rennie, V.A. Bowell, M.J. Bell, and A.B. Lawrence. 2006. Housing system, milk production, and zero-grazing effects on lameness and leg injury in dairy cows. Journal of Dairy Science 89(11):4259-4266.

Health Care Without Harm. 2018. Blended burgers: A meat reduction strategy. Reston, VA: Health Care Without Harm. https://noharm-uscanada. org/blendedburgerstudy.

Horst, M., and A. Marion. 2018. Racial, Ethnic, and Gender Inequities in Farmland Ownership and Farming in the US. Agriculture and Human Values 36:1-16.

IDALS (Iowa Department of Agriculture and Land Stewardship). 2017. The Iowa Nutrient Reduction Strategy: Revised Version December 2017. Ames, IA: Iowa Department of Agriculture and Land Stewardship, Iowa Department of Natural Resources, and Iowa State University. http:// www.nutrientstrategy.iastate.edu/documents.

IDALS. 2020. First Iowa Meat Processor Approved for Cooperative Interstate Shipment Program. Des Moines, IA: Iowa Department of Agriculture and Land Stewardship. https://iowaagriculture.gov/news/ story-city-locker-first-approved-cis-program.

Jacobson, L., M.B. David, and L.E. Drinkater. 2011. A spatial analysis of phosphorus in the Mississippi River basin. Journal of Environmental Quality 40(3):931-941.

Jewett, J. 2018. Grazing Dairies: Production, Income \& Expenses. Green Lands Blue Waters. https://greenlandsbluewaters.org/wp-content/ uploads/2020/04/Dairy_Grazing_Production_ Income_Expenses.pdf.

Knapp, A.K. J.M. Blair, J.M. Briggs, S.L. Collins, D.C. Hartnett, L.C. Johnson, and E.G. Towne. 1999. The keystone role of bison in North American tallgrass prairie. BioScience 49(1):39-50. 
Lal, R. 2020. Regenerative agriculture for food and climate. Journal of Soil and Water Conservation 75(5):123A-124A.

Lwiwski, T.C., N. Koper, and D.C. Henderson. 2015. Stocking Rates and Vegetation Structure, Heterogeneity, and Community in a Northern Mixed-Grass Prairie. Rangeland Ecology \& Management 68(4):322-331.

Lyons, J., B.M. Weigel, L.K. Paine, and D.J. Undersander. 2000. Influence of intensive rotational grazing on bank erosion, fish habitat quality, and fish communities in southwestern Wisconsin trout streams. Journal of Soil and Water Conservation 55:271-276.

MDC (Missouri Department of Conservation). 2014. Missouri's Nutrient Loss Reduction Strategy: A collaborative strategy to bring practical nutrient reductions to Missouri's waters. Jefferson City, MO: Missouri Department of Natural Resources. https://dnr.mo.gov/env/wpp/mnrsc/docs/nlrsstrategy-2014.pdf.

MDNR (Missouri Department of Natural Resources). 2018. Missouri Nutrient Loss Reduction Strategy, 2018 Update. Jefferson City, MO: Missouri Department of Natural Resources. https://dnr.mo.gov/env/wpp/mnrsc/docs/nlrs2018-update.pdf.

Native Energy. n.d. Help Build. Burlington, VT: Native Energy. https://native.eco/our-approach/ help-buildtm/.

NSAC (National Sustainable Agriculture Coalition). 2020. Presidential Transition Briefing Papers: Food and Agriculture Priorities for Administrative Action. Washington, DC: National Sustainable Agriculture Coalition. https://sustainableagriculture.net/ wp-content/uploads/2020/12/NSAC-FinalTransition-Team-Document-2020.pdf.

Paine, L.K., and C.A. Ribic. 2002. Comparison of riparian plant communities under four land management systems in southwestern Wisconsin. Agriculture, Ecosystems, and Environment 92:93-105.

Paine, L.,D. Undersander, and M. Casler. 1999. Pasture growth, production, and quality under rotational and continuous grazing management. Journal of Production Agriculture 12(4):569-577.

Park, J.Y., S. Ale, W.R. Teague, and S.L. Dowhower. 2017a. Simulating hydrologic responses to alternate grazing management practices at the ranch and watershed scales. Journal of Soil and Water Conservation 72(2):102-121. https://doi. org/10.2489/jswc.72.2.102.

Park, J.Y., S. Ale, W.R. Teague, and J. Jeong. 2017b. Evaluating the ranch and watershed scale impacts of using traditional and adaptive multipaddock grazing on runoff, sediment and nutrient losses in North Texas, USA. Journal of Agriculture, Ecosystems and Environment 240:32-44.

Peters, D. 2002. Revisiting the Goldschmidt Hypothesis: The Effect of Economic Structure on Socioeconomic Conditions in the Rural Midwest. Jefferson City, MO: MERIC, Missouri Department of Economic Development.

Provenza, F.D., S.L. Kronberg, and P. Gregorini. 2019. Is grassfed meat and dairy better for human and environmental health? Frontiers in Nutrition 6:26.

Rawls, W.J., Y.A. Pachepsky, J.C. Ritchie, T.M. Sobecki, and H. Bloodworth. 2003. Effect of soil organic carbon on soil water retention. Geoderma 116(1-2):61-76.

Rosset, P. 2000. The multiple functions and benefits of small farm agriculture in the context of global trade negotiations. Development 43:77-82.

Rotz, C.A., K.J. Soder, R.H. Skinner, C.J. Dell, P.J. Kleinman, J.P. Schmidt, and R.B. Bryant 2009. Grazing can reduce the environmental impact of dairy production systems. Forage and Grazinglands 7(1):1-9.

Smolski, A.R. 2019. Stemming the Exploitation of Immigrant Farm Labor. Contexts 18(2):70-71.

Taylor, R.E., and T.G. Field. 1995. Achieving Cow/ Calf Profitability through Low-Cost Production. Paper presented at the Range Beef Cow Symposium, Gering, NE, December 5-7, 1995.

Temple,S.A.,B.M.Fevold,L.K.Paine,D.J.Undersander, and D.W. Sample. 1999. Nesting birds and grazing cattle: Accommodating both on midwestern pastures. Studies in Avian Biology 19:196-202.

Thompson, L.R., and J.E. Rowntree. 2020. Invited Review: Methane sources, quantification, and mitigation in grazing beef systems. Applied Animal Science 36(4): 556-573.

Tuck B., and R. Pesch. 2019. Developing a production function for small-scale farm operations in central Minnesota. Journal of Agriculture, Food Systems, and Community Development 8(C):17-36.

UCS (Union of Concerned Scientists) and HEAL Food Alliance. 2020. Leveling the Fields: Creating Farming Opportunities for Black People, Indigenous People, and Other People of Color. Cambridge, MA, and Oakland, CA: Union of Concerned Scientists and HEAL Food Alliance. https://www.ucsusa.org/sites/default/ files/2020-06/leveling-the-fields.pdf.

USAFacts. 2019. Federal Farm Subsidies: What the Data Says. USAFacts. https://usafacts.org/ articles/federal-farm-subsidies-what-data-says/.

USDA (United States Department of Agriculture). 2019. FY 2020 Budget Summary. Washington, DC: USDA Office of Budget and Program Analysis. https://www.obpa.usda.gov/budsum/ fy2020budsum.pdf.
USDA NASS (National Agricultural Statistics Service). 2017. Agriculture Census. Historical Highlights: 2017 and Earlier Years. Washington, DC: USDA National Agricultural Statistics Service. https://www.nass.usda.gov/Publications/ AgCensus/2017/Full_Report/Volume_1, Chapter_1_US/st99_1_0001_0001.pdf.

USDA NRCS (National Resource and Conservation Service) Grazing Lands Technology Institute. 1996. Dairy Farmer Profitability Using Intensive Rotational Stocking: Better grazing management for pastures. Washington, DC: USDA Natural Resources Conservation Service. https://www. nrcs.usda.gov/Internet/FSE_DOCUMENTS/ nrcs142p2_018799.pdf.

VanDerPol,J., and L.VanDerPol.2020. Processing plants as community resources. The Land Stewardship Letter. https://landstewardshipproject.org/repository/1/3298/1sl_no_2_2020_covid.pdf.

Walker, J. 1994. Multispecies grazing: The ecological advantage. Sheep Resource Journal Special Issue:52-64

Waller, P.J. 2006. Sustainable nematode parasite control strategies for ruminant livestock by grazing management and biological control. Animal Feed Science and Technology 126(3-4):277-289.

Wisconsin DNR (Department of Natural Resources). 2020. Wisconsin's Water Quality Trading. Madison, WI: Wisconsin Department of Natural Resources. https://dnr.wi.gov/topic/ wastewater/waterqualitytrading.html.

Winsten, J.R., E. Gorman, and A. Gravitz. 2020. Coordinating a "basket of incentives" to facilitate resilience in the dairy sector. Journal of Soil and Water Conservation 75(6):144A-149A. https:// doi.org/10.2489/jswc.2020.1005A.

Winsten, J.R., C.D. Kerchner, A. Richardson, A. Lichau, and J.M. Hyman. 2010. Trends in the Northeast dairy industry: Large-scale modern confinement feeding and management-intensive grazing. Journal of Dairy Science 93:1759-1769.

Winsten, J.R., R.L. Parsons, and G.D. Hanson. 2000. The profitability of management-intensive grazing for Northeastern dairy farms. Agricultural and Resource Economics Review 29(2):1-9. 